\title{
Ambiguidades no discurso fotográfico: produção de sentido sobre a degradação do solo
}

\author{
Ambiguities in photographic discourse: production of meaning about soil \\ degradation
}

\section{Marcelo Pereira da Silva}

Pós-doutor em Comunicação, docente permanente do Mestrado Interdisciplinar em "Linguagens, Mídia e Arte" e dos cursos de Relações Públicas, Jornalismo e Mídias Digitais da Pontifícia Universidade Católica de Campinas (PUCCAMP).

\section{Ana Maria Dantas de Maio}

Doutora em Comunicação Social pela Universidade Metodista de São Paulo. Mestre em Comunicação pela Universidade Estadual Paulista (USP). Graduada em Comunicação Social (habilitação Jornalismo) pela Universidade Estadual de Londrina. Jornalista do Núcleo de Comunicação Organizacional da Embrapa Pecuária Sudeste em São Carlos (SP).

Submetido em 14 de Junho de 2020 Aceito em 14 de Setembro de 2020

\section{RESUMO}

Com base em arcabouço teórico-metodológico que envolve os estudos do discurso e de imagem, analisa-se uma fotografia publicada em 2019, pelo Portal G1, que ilustra uma matéria sobre os efeitos da erosão do solo sobre a produção agrícola. Depreendem-se alguns sentidos pregnantes na enunciação imagética, considerando que as fotografias contribuem para informar, dão mais ênfase às reportagens e desempenham funções estéticas. Além disso, constituem sentidos que podem corroborar estereótipos e reificações acerca do universo rural, suas identidades e idiossincrasias. Infere-se, com este estudo, que o discurso fotográfico apresenta ambiguidade ao retratar um conteúdo que permite dupla leitura. A condução pela interpretação da ideia de desertificação se dá pelo elemento verbal da legenda. Como fotografias não transmitem conceitos abstratos, cabe ao interlocutor atribuir sentidos que se conectem ao seu repertório, num ato de reforço ou contradição à intencionalidade dos sujeitos enunciadores.

PALAVRAS-CHAVE: Discurso fotográfico; Fotojornalismo; Degradação de solo; Análise de discurso; Fotografia.

Dossiê 0 Pensamento Ecológico - https://revistaecopos.eco.ufrj.br/

ISSN $2175-8689$ - v. 23, n. 2, 2020

DOI: 10.29146/eco-pos.v23i2.27511 


\section{ABSTRACT}

Based on a theoretical-methodological framework that involves discourse and image studies, this paper analyzes a photograph published in 2019 by Portal G1 that illustrates a news story on the effects of soil erosion on agricultural production. Some pregnant meanings can be found in the image enunciation, considering that the photographs contribute to inform, to give more emphasis to the reports and perform aesthetic functions. They constitute meanings that might corroborate stereotypes and reifications related to the rural universe, its identities and idiosyncrasies. It is inferred in this study that the photographic discourse is ambiguous in portraying a content that allows double reading. The interpretation of the idea of desertification takes place through the verbal element of the legend. As photographs do not convey abstract concepts, it is up to the interlocutor to assign meanings that are connected to his repertoire, in an act that could reinforce or contradict the intentions of the enunciator.

KEYWORDS: Photographic discourse; Photojournalism; Soil degradation; Discourse analysis; Photography.

\section{RESUMEN}

Basado en un marco teórico-metodológico que involucra los estudios del discurso e imagen, se analiza una fotografía publicada en el 2019 por Portal G1, que ilustra una noticia sobre los efectos de la erosión del suelo en la producción agrícola. Se han sacado algunos sentidos de la enunciación de la imagen, considerando que las fotografías contribuyen para informar, dan más énfasis a los reportajes y desempeñan funciones estéticas. Constituyen sentidos que pueden corroborar estereotipos y reificaciones sobre el universo rural, sus identidades e idiosincrasias. Se infiere, con este estudio, que el discurso fotográfico presenta ambigüedad al retratar un contenido que permite una doble lectura. La conducción por la interpretación de la idea de desertificación se lleva a cabo a través del elemento verbal de la leyenda. Como las fotografías no transmiten conceptos abstractos, depende del interlocutor asignar sentidos de acuerdo con su repertorio, en un acto de refuerzo o contradicción de la intencionalidad de los sujetos enunciadores.

PALABRAS CLAVE: Discurso fotográfico; Fotoperiodismo; Degradación del suelo; Análisis del discurso; Fotografía.

\section{Introdução}

Este artigo desenvolve uma análise do discurso fotográfico de uma imagem publicada em contexto jornalístico sobre o tema "degradação de solo" no portal de notícias G1. O objetivo é depreender alguns sentidos da imagem, verificar sua conexão com a notícia e investigar as possíveis ambiguidades em sua interpretação.

Dossiê 0 Pensamento Ecológico - https://revistaecopos.eco.ufrj.br/

ISSN 2175-8689- v. 23, n. 2, 2020

DOI: 10.29146/eco-pos.v23i2.27511 
O texto verbal não é objeto de análise deste estudo, embora sejam consideradas as relações entre a imagem e os demais elementos jornalísticos.

A fundamentação teórica se baseia na análise discursiva da imagem por meio de conceituações de Barthes (1984, 2009), para quem a imagem fotográfica e o objeto representado partilham sentidos da história do mundo, posto que as fotografias se tornam certificados de presença; de Sousa (2004a, 2004b), que vê o objetivo do fotojornalismo no informar, contextualizar, formar, esclarecer e/ou opinar; e de Coutinho (2008), cujos estudos indicam que as imagens constituem uma maneira de olhar registrada pela ação humana.

A metodologia aplicada foi proposta por Soares e Ferreira (2017), ao levarse em conta focalização, enquadramento ou panorama simbólico, apoiados em estudos de Barthes e na psicologia da percepção de Gombrich (1995). Este último explora mecanismos acionados pelo espectador na observação de imagens fixas e outros pontos vinculados à interpretação de imagens. As investigações sobre história da arte de Gombrich apresentam intersecção com a Análise de Discurso (AD) ao refletirem sobre "a influência da cultura e do contexto na interpretação da imagem, a participação ativa do leitor na produção de sentido, a influência do texto verbal para o processo de leitura da imagem e a interdependência entre produtores e leitores na produção de sentido" (Soares; Ferreira, 2017, p. 185).

Indica-se com este estudo que, embora a fotografia no jornalismo apresente relação com os elementos verbais que a acompanham, ela detém certa autonomia no funcionamento do discurso, na produção de sentidos e nos espaços do dizer que se manifestam através da enunciação fotográfica.

A imagem se inscreve no contexto de uma máquina midiática de processar informações e produzir sentido social, aportando ao jornalismo um trajeto ocular multiorientado do espaço de escritura (Charaudeau, 2019). Nessa esteira, os resultados da análise discursiva assinalam que a fotografia reforça e amplifica a mensagem proposta no título, isto é, que a produção agrícola foi afetada por algum fenômeno. A proporção dessa ameaça e a causa — possível erosão do solo - migram para a seara do imaginário do interlocutor. A interpretação simbólica é ambígua e

Dossiê o Pensamento Ecológico - https://revistaecopos.eco.ufrj.br/

ISSN $2175-8689-$ v. 23, n. 2, 2020

DOI: 10.29146/eco-pos.v23i2.27511 
dependerá de fatores como repertório, modelo mental e posição ideológica do sujeito observador.

\section{Proposta metodológica}

A escolha do enunciado sobre degradação de solo foi intencional. A princípio, a ideia era fazer uma análise de discurso de uma matéria jornalística sobre o tema (rural) levado ao público leigo (urbano). Após a submissão da palavra-chave “degradação de solo" na plataforma de buscas Google em 2019, o texto foi localizado e a análise foi iniciada em 2020. Durante o processo, no entanto, verificou-se que texto e imagem apresentavam riqueza de detalhes que se perderiam em uma investigação única. Optou-se por produzir, então, duas análises: uma da linguagem verbal e outra apenas da fotografia, que é o objeto deste artigo.

O corpus selecionado ilustra matéria jornalística veiculada na internet em maio de 2019, produzida pela agência de notícias espanhola EFE e replicada em alguns portais (Erosão..., 2019). A escolha do G1 levou em conta o fato de se tratar de um veículo de acesso geral, e não segmentado. Com essa seleção, é possível realizar a análise com base em um receptor potencialmente desvinculado do ambiente rural.

Princípios da análise de discurso da escola francesa fundamentam teoricamente esta investigação, que buscou em estudiosos da análise discursiva de imagens alguns conceitos relevantes para validar e aprofundar a interpretação e a depreensão de sentidos pregnantes na imagem jornalística. A aproximação com a psicologia da percepção de Gombrich (1995) ocorreu em função da metodologia escolhida.

A $\mathrm{AD}$ se apresenta como base teórico-metodológica consistente porque configura um recorte, uma possibilidade de leitura do discurso, além de considerar suas condições de produção. A contextualização é uma premissa indispensável tanto para análises textuais quanto de imagem. Decifrar traços apensos na fotografia e nos componentes que a acompanham (legenda, crédito, filtros, título, textos internos e externos) permite (re)conhecer as circunstâncias em que o discurso foi produzido. 
Na concepção metodológica proposta por Soares e Ferreira (2017), a fotografia pode se apresentar sob três categorias: focalização, enquadramento ou panorama simbólico.

Nessa perspectiva, as imagens de focalização são caracterizadas pela produção de um sentido direcionado ao acontecimento representado, ao fato que está sendo mostrado pela imagem. Sua força discursiva, com isso, está centrada no histórico valor comprobatório do dispositivo fotográfico socialmente constituído. Isso não quer dizer que apenas esse tipo de fotografia possui tal característica, mas que esse é o traço discursivo marcante da categoria focalização. (Soares; Ferreira, 2017, p. 195).

Enquanto as imagens classificadas como "focalização" produzem sentido com base no acontecimento retratado, as fotografias acolhidas na categoria "enquadramento" exigem um grau superior de sofisticação na atribuição de sentido. Soares e Ferreira (2017, p. 191-192) pontuam que "as imagens de enquadramento se aproveitam do fato representado e estabelecem uma relação de sentido que extrapola o que é visto na cena, resgatando outros acontecimentos". Já a categoria designada "panorama simbólico" contempla imagens que vinculam a cena retratada a memórias históricas, visto que a "dinâmica entre texto e contexto vincula um fato presente a acontecimentos do passado, geralmente de relevância histórica" (Soares; Ferreira, 2017, p. 193).

\section{A fotografia jornalística como discurso}

Ao conceber essa metodologia, os autores combinaram a análise da narrativa da imagem de Barthes com a psicologia da percepção, que problematiza ilusões, paradoxos e ambiguidades na interpretação de imagens. Este estudo busca conectar essa composição a pressupostos teóricos erigidos por Charaudeau e Maingueneau (2016) que, ao abordarem a questão da ambiguidade na análise discursiva de forma mais ampla, a percebem como "[...] um fenômeno ligado à discursivização de um enunciado. Esse fenômeno se produz sempre que uma mesma frase apresente vários 
sentidos e seja, então, susceptível de ser interpretada de diversas maneiras" (Charaudeau; Maingueneau, 2016, p. 35) ${ }^{1}$.

Nem sempre consciente, a ambiguidade, segundo Gombrich (1995), é a chave dos problemas que acometem este processo. Em uma análise, o autor relata que é "puro acidente" interpretar a imagem do contorno de uma mão (figura 1) como direita ou esquerda, haja vista ser "impossível dizer se é a mão esquerda vista de frente ou a mão direita vista de costas. E, todavia, quando confrontados com um desenho como esse, ficamos pasmos com a inesperada falta de informação" (Gombrich, 1995, p. 250).

Figura 1: Contorno da mão ambígua

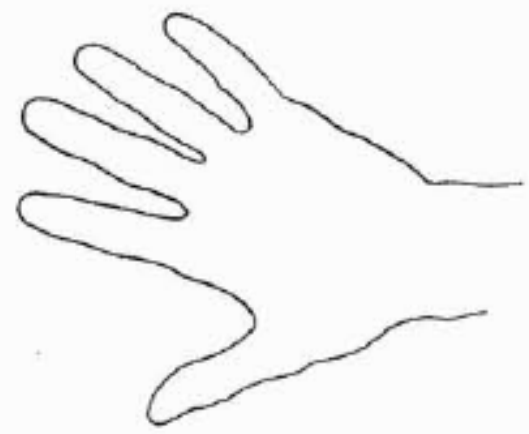

Fonte: Gombrich, 1995.

De acordo com o historiador, a experiência de sobrepor as próprias mãos esquerda e direita - ao desenho é um exercício que permite vivenciar e aceitar a ambiguidade. Se essa falta de clareza está presente em um desenho simples como o contorno da mão, convém adotar cautela nas análises de imagens mais complexas, como a que este estudo se propõe a promover.

Um dos pontos comuns entre as diferentes significações da palavra imagem, seja ela material ou imaterial, natural ou não, visual ou não, é "algo que se assemelha a outra coisa" (Joly, 1996, p. 38), mesmo quando tratamos de uma imagem não

\footnotetext{
${ }^{1}$ Como exemplo, Charaudeau e Maingueneau citam o enunciado "Tenho 30 anos", que, por falta de contextualização, não permite avaliar se o sentido atribuído a essa idade seria de jovem demais ou velho demais.
}

Dossiê 0 Pensamento Ecológico - https://revistaecopos.eco.ufrj.br/

ISSN 2175-8689 - v. 23, n. 2, 2020

DOI: 10.29146/eco-pos.v23i2.27511 
concreta, como a mental. Pensar a imagem do ponto de vista da semelhança ou da analogia é pô-la na categoria da representação.

A análise narrativa da imagem proposta por Roland Barthes, assim, ressalta a ligação direta entre a imagem fotográfica e o objeto representado, donde a fotografia partilharia a própria história do mundo. As fotografias são certificados de presença, e trazem consigo seu referente, "ambos atingidos pela mesma imobilidade amorosa ou fúnebre, no âmago do mundo em movimento: estão colados um ao outro" (Barthes, 1984, p. 29).

$\mathrm{Na}$ esteira deste pensamento, Coutinho defende que cada fotografia representa determinado recorte da realidade de um fato, situação ou acontecimento, pressupondo várias escolhas efetuadas quando entra em ação a "tesoura" do fotógrafo. As imagens não constituem a realidade objetiva, mas uma maneira de olhar registrada pela ação humana (Coutinho, 2008), considerando os efeitos de sentido que se instituem entre a imagem e o olhar (Souza, 2015). Enquanto a leitura da palavra pede uma direcionalidade (da esquerda para a direita, de cima para baixo no sistema ocidental), a da imagem é multidirecionada, dependendo do olhar e da subjetividade de cada sujeito.

Já Soares e Ferreira (2017) atentam para a necessidade de apreciar o funcionamento discursivo próprio das fotografias jornalísticas, "enquanto matéria significante visual, destacando sua relação com o texto, mas também tendo em conta uma relativa autonomia da imagem" (Soares; Ferreira, 2017, p. 179).

Barthes (2009), por sua vez, busca compreender e desvelar, desde o início da década de 1980, o que subjaz às fotografias, o que portam no campo do invisível, o que não pode ser visto a "olho-nu". Para ele, a fotografia reproduz ao infinito o que ocorreu apenas uma vez (um acontecimento como um acidente aéreo), repetindo de modo mecânico o que jamais acontecerá material e existencialmente da mesma maneira, já que o momento ímpar apreendido pelo sujeito-fotógrafo não mais poderá voltar com as mesmas características, cenário, cor, personagens, ângulos, iluminação, enquadramentos etc.

A fotografia não mostra o tempo de forma linear, sequencial, representando um tempo próprio, peculiar, distinto do tempo cronometrado pelo relógio. Ela 
entrega-se ao olhar do Outro sem pedir licença e torna possível um passeio pela memória psicológica e discursiva, e pelo tempo, tendo em conta que ela instala não a consciência de estar lá da coisa, mas "uma consciência do ter-estado-lá". Essa reflexão aponta para uma nova categoria de espaço-tempo, um "local imediato e temporal anterior: na fotografia produz-se uma conjunção ilógica entre o aqui e o outrora" (Barthes, 2009, p. 36).

Barthes detalha os sentidos denotativo e conotativo da imagem. A imagem denotada estaria mais próxima da realidade, pois não há uma imagem literal no sentido mais puro. Compreende-se, para os fins deste artigo, que a mensagem denotada pode emergir como uma espécie de estado primitivo da imagem; de acordo com Barthes (2009, p. 34), "desembaraçada utopicamente das suas conotações, a imagem, tornar-se-ia radicalmente objetiva, isto é, ao fim e ao cabo, inocente".

Em relação à conotação, Barthes (2009) diz que ela arrasta um significado estético, como a entonação, que é um significante isolado da linguagem. Investida de um caráter cultural, a imagem, no nível da conotação, pode ter um variado número de leituras não-anárquicas, já que variam de acordo com os saberes dos quais a imagem se reveste. A língua da imagem não é somente um conjunto de palavras emitidas, mas um somatório de palavras recebidas, e carece incluir as surpresas provocadas pelo sentido.

A variabilidade das leituras não pode, pois, ameaçar a "língua" da imagem, se admitirmos que esta língua é composta por idioletos, léxicos ou subcódigos: a imagem é inteiramente atravessada pelo sistema do sentido, exatamente como o homem se articula até o fundo de si próprio em linguagens distintas. (Barthes, 2009, p. 38).

A fotografia medeia a relação acontecimento-sujeito, propiciando ao receptor imaginar o cenário e a ação do registro fotográfico. Mais especificamente, as fotografias jornalísticas são produtos do fotojornalismo, ao qual cabe a tarefa de informar, contextualizar, oferecer conhecimento, formar, esclarecer ou opinar por meio da cobertura de assuntos de interesse jornalístico e social (Sousa (2004b).

Dossiê o Pensamento Ecológico - https://revistaecopos.eco.ufrj.br/

ISSN $2175-8689-$ v. 23, n. 2, 2020

DOI: 10.29146/eco-pos.v23i2.27511 
Assim, na perspectiva da análise de discurso, cabe investigar como jornalismo e fotografia se entrelaçam para constituir sentido junto a um receptor heterogêneo, eclético, anônimo, desconhecido. Um dos grandes desafios que se impõem é que a interpretação visual parece mais ampla do que a textual, pois exige, teoricamente, um conhecimento menos profundo. 0 homem urbano - ou homo urbis - alfabetizado ou não, é capaz de interpretar uma imagem. Já o estudo dessa interpretação se problematiza exponencialmente porque faz-se necessário, portanto, considerar o grau de subjetividade e as diferentes idiossincrasias interpostas nas variadas formas de ver e ler o mundo.

\section{Contextualização: condições de produção da imagem}

Toda análise de discurso requer que se conheçam suas condições de produção, ou seja, o contexto sócio-histórico em que foi criado e os elementos ou circunstâncias que condicionam sua existência. No ano em que o conteúdo foi publicado, 2019, o mundo vivia - e ainda vive - o dilema de buscar soluções que minimizem as emissões de gases de efeito estufa para tentar retardar os efeitos das mudanças climáticas. Paralelamente, a Organização das Nações Unidas divulga que 820 milhões de habitantes do planeta passam fome (ONU, 2019).

Em fóruns internacionais, a solução preconizada é a produção mais sustentável de alimentos, garantindo que a agricultura possa operar dentro de padrões aceitáveis (Pereira, 2019; Grossi, 2019). A ciência propõe tecnologias que permitam um equilíbrio entre as ideologias ambientalista e ruralista, uma lógica fuzzy que flexibilize posições antagônicas. 0 discurso completo em análise se refere a estudos que comprovariam o impacto da degradação do solo na produção agrícola. A imagem retrata um possível efeito dessa degradação, chamado na legenda de desertificação.

O perfil sociodemográfico de internautas brasileiros levantado pelo Ipea Instituto de Pesquisa Econômica Aplicada (Silva; Ziviani; Ghezzi, 2019) — indica que o interlocutor deste enunciado pode ser descrito como predominantemente adulto, urbano, masculino, branco, com trabalho em atividade remunerada e alto grau de

Dossiê o Pensamento Ecológico - https://revistaecopos.eco.ufrj.br/

ISSN 2175-8689 - v. 23, n. 2, 2020

DOI: 10.29146/eco-pos.v23i2.27511 
escolaridade. Este é o perfil prevalente entre usuários que costumam usar a Internet para ler jornais. Outra inferência possível é que sejam leitores interessados em temas como agronegócio ou meio ambiente.

A fotografia que ilustra o enunciado está inserida neste contexto. 0 conteúdo completo foi reproduzido abaixo para facilitar a análise. A imagem da notícia (figura 2) mostra os elementos iniciais, como título, subtítulo, foto e legenda. Sob ela, em itálico, está copiado o texto da matéria. Para atribuir sentido à imagem, é necessário conhecer os elementos que a acompanham.

Figura 2: Reprodução dos elementos iniciais da notícia

61 NATUREZA Q Q

\section{Erosão do solo pode reduzir rendimento de plantações pela metade, diz ONU}

Em congresso internacional, 500 especialistas alertam para os riscos que a degradača do solo oferece ao meio ambiente e à agricultura.

7. Por Agência EFE

If $y$ (i) i

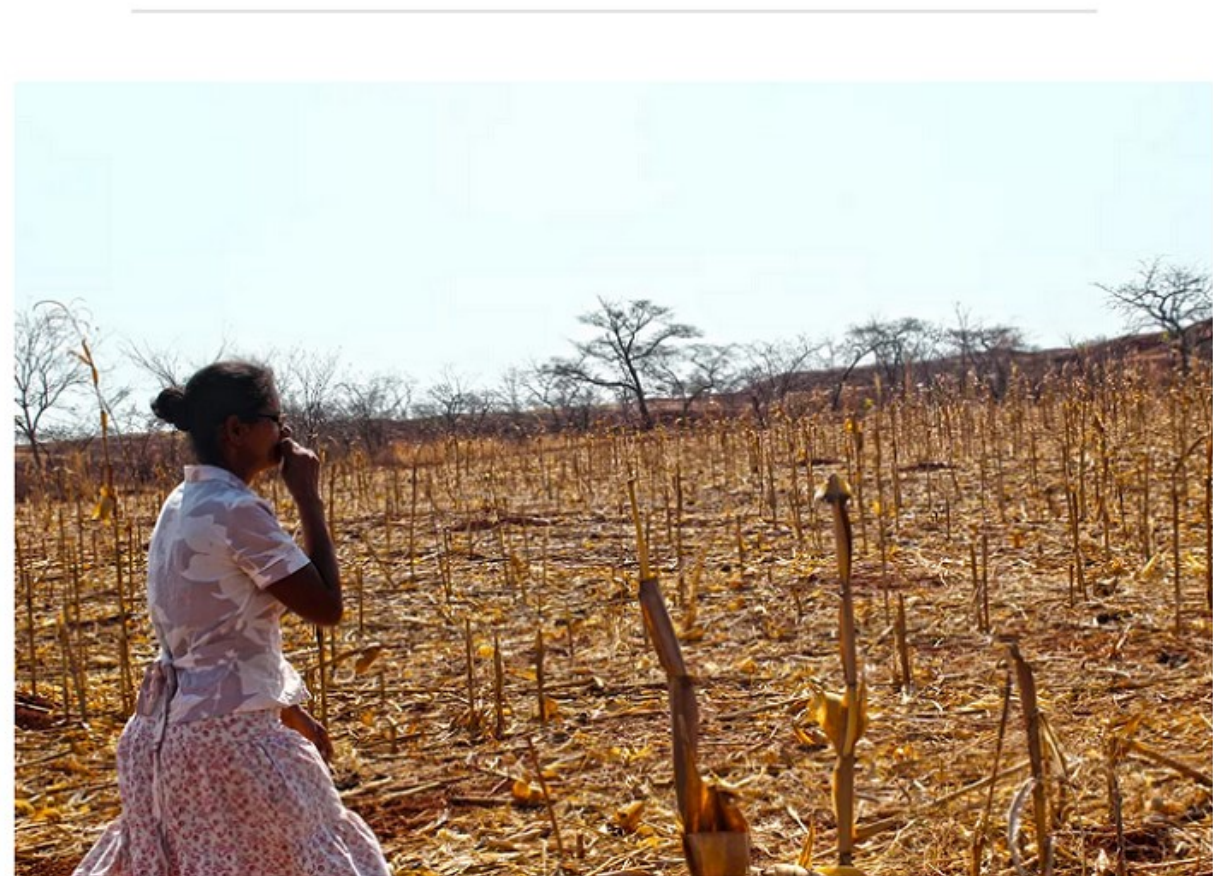

Dossiê o Pensamento Ecológico - https://revistaecopos.eco.ufrj.br/

ISSN 2175-8689 - v. 23, n. 2, 2020

DOI: 10.29146/eco-pos.v23i2.27511 
A erosão do solo pode causar perdas de até $50 \%$ no rendimento de algumas culturas agrícolas, uma ameaça que 500 especialistas e responsáveis analisam a partir desta quarta-feira (15) em um congresso internacional que acontece em Roma.

A diretora-geral adjunta da Organização da ONU para a Alimentação e a Agricultura (FAO) Maria Helena Semedo detalhou na apresentação do simpósio, que terá três dias de duração, que a agricultura intensiva, a lavoura, a monocultura, a pecuária extensiva, a expansão urbana, o desmatamento, a indústria e a mineração contribuem para a aceleração da erosão.

Calcula-se que a cada cinco segundos, uma superfície de terra equivalente a um campo de futebol é degradada e que, seguindo a tendência atual, mais de 90\% de todos os solos do planeta podem estar desgastados até 2050.

A parte positiva é que "os solos podem ser recuperados em praticamente qualquer situação com medidas como coleta de água, proteção com coberturas vegetais e terraços", indicou Semedo, que incentivou agricultores, cientistas e políticos a criarem programas conjuntos de combate à erosão.

O ministro de Pecuária do Uruguai, Enzo Benech, usou como exemplo um plano nacional para a utilização de solos, que é de cumprimento obrigatório para qualquer produtor no país, que "produz comida para um número dez vezes maior que sua população".

"As novas tecnologias permitem que tenhamos todo o país sob controle", disse o responsável uruguaio, que ressaltou que nos últimos 50 anos foram recolhidas informações sobre a incidência de chuvas e as características do solo para garantir a capacidade de uso desses recursos.

O subsecretário executivo da Convenção das Nações Unidas para a Luta contra a Desertificação, Pradeep Monga, assinalou que o rendimento agrícola no mundo todo foi afetado pela perda de nutrientes do solo e pela exposição à água.

Além disso, Monga acrescentou que a erosão contribui para quase $24 \%$ das emissões de gases do efeito estufa procedentes da ação sobre a terra e, para evitar isto, pediu a idealização de soluções que ajudem, de forma conjunta, a restaurar solos, proteger a biodiversidade e lutar contra a mudança climática. 
O acadêmico da Universidade Católica de Louvain (Bélgica), Jean Poesen, explicou que as depressões e a erosão sob a terra causadas pela água podem danificar o solo seriamente, mas que é necessário estudar melhor esses fenômenos.

Além disso, Poesen advertiu sobre outros fatores, como a pecuária extensiva e a colheita de tubérculos, como batatas e beterraba, que, somente na União Europeia, calcula-se que são responsáveis pela erosão de quase 15 milhões de toneladas de solo por ano. EFE

\section{Imagem focalizada: sentidos pregnantes no discurso fotográfico}

Enquanto o conteúdo linguístico-discursivo explora a erosão de solo e o evento que vai discutir o tema em Roma, a imagem que acompanha o texto não mostra diretamente nem a erosão, nem o congresso e as autoridades participantes. Para a análise discursiva da imagem, é imprescindível atentar para sua descrição, um componente chamado de legenda no fotojornalismo.

A legenda é um elemento relevante para a análise da fotografia, e até mesmo o tamanho reduzido em que aparece sob a imagem significa. Diz o texto: "Desertificação já é um desafio para a agricultura em comunidades no semiárido brasileiro - Foto: Pedro Santiago/G1". Em discursos do gênero jornalístico, é padrão que as legendas sejam escritas com um tamanho de letra menor do que o texto da matéria. Essa prática, no entanto, pode desestimular a leitura e, por conseguinte, prejudicar a compreensão do conteúdo na relação entre a linguagem verbal e não verbal que constituem a enunciação jornalística.

O foco da legenda está em assunto correlato, a desertificação, um efeito da degradação do solo. A leitura da legenda e do crédito, que identifica a autoria da foto, sugere que a imagem foi obtida em arquivo para uso ilustrativo, e não produzida especificamente para a matéria em questão.

Um olhar denotativo sobre o formato da imagem aponta para um retrato retangular, na posição horizontal e colorido. 0 conteúdo abarca uma mulher magra, usando uma blusa e uma saia estampadas, óculos, cabelo preso em um coque e com a mão direita na boca. Ela aparece de perfil, olhando em direção a uma plantação

Dossiê o Pensamento Ecológico - https://revistaecopos.eco.ufrj.br/

ISSN $2175-8689$ - v. 23, n. 2, 2020

DOI: 10.29146/eco-pos.v23i2.27511 
seca, em tom dourado, que ocupa dois terços do quadro. 0 dia está ensolarado e, ao fundo, aparecem algumas árvores desfolhadas. A denotação vai ao encontro do que Barthes (2009) chamou de óbvio da fotografia, que se apresenta ao entendimento de modo inteligível, apoiado na ciência e na racionalidade do mundo. A cena é constituída por elementos que, supostamente, integram o imaginário social em relação ao universo rural e suas peculiaridades.

Nesse caminho, toda fotografia reproduz o que aconteceu somente uma vez, pois o momento ímpar apreendido pelo fotógrafo não mais poderá retornar com os mesmos atributos, a saber: cores, angulações, personagens, iluminação, enquadramentos, etc., instalando a consciência de ter estado lá do fotógrafo (Barthes, 2009), que se torna testemunha ocular do acontecimento. Dessa forma, tem-se que a máquina fotográfica porta capacidade, conforme Sousa (2004b), de "arrancar" da realidade um fragmento de tempo em determinado espaço social que otimiza o limitado poder de visão.

A imagem gera, também, interpretações conotativas. É possível inferir que se trata de uma moradora de região árida, provavelmente uma agricultora, vestida para uma situação de não-trabalho - pois saias não são peças comumente usadas na rotina da atividade rural. Por meio do vestuário pode-se depreender que a personagem se preparou para encontrar o fotógrafo. A mão próxima à boca pode significar tristeza, angústia ou algum outro sentimento.

O cenário, supostamente uma plantação de milho que já foi colhido, deixa apensos sentidos de seca, devastação e possibilidade de fome e sede. Esses componentes enleiam-se a sentidos de futuro, esperança e expectativa diante de um mundo porvir que se materializa no olhar e na posição da cabeça ao horizonte da mulher que compõem a imagem. Representando determinado recorte da realidade, as escolhas do fotógrafo evidenciam a ação de sua "tesoura do real", visto que a imagem em análise não constitui a realidade objetiva, mas um modo de olhar levado a efeito pela atividade humana (Coutinho, 2008), o qual pode constituir sentidos estereotipados e reificantes que, no lugar de fomentar a sensibilidade social no tocante ao universo rural, pode reforçar ideias preconcebidas e triviais. 
Considera-se, ancorado em Soares e Ferreira (2017), que a conotação fotográfica depende da cultura partilhada entre produtores e leitores, acrescentando que as duas dimensões - denotativa e conotativa - precisam ser entendidas como instâncias integradas, sinérgicas, responsáveis pela produção de sentidos globais e dependentes. Por sua vez, Joly (1996) assevera que a imagem é uma mensagem visual composta de diversos signos de expressão e comunicação, defendendo que ela - a imagem - sempre vai constituir novas mensagens para as alteridades em jogo na enunciação, visto que o dialogismo imagético constitui um movimento polifônico e policrômico infindável.

De acordo com o Sousa (2004a), imagens não conseguem transmitir conceitos abstratos. No caso do fotojornalismo, "os elementos representativos devem ter um posicionamento tal que o observador consiga atribuir claramente à mensagem fotográfica um determinado sentido" (Sousa, 2004a, p. 115).

A observação do ângulo, da composição, do plano, da profundidade de campo, da iluminação, das cores e de outros elementos da fotografia ajuda a construir uma análise discursiva da imagem. Há um sentido em compor a cena com um peso maior para a plantação seca do que para a personagem. Assim como na análise textual, pode-se questionar alguns silenciamentos da fotografia: por que não um personagem masculino? Por que a mulher não aparece do lado direito do quadro? Por que não veste roupa de trabalho? Por que não está de frente? Por que reservar dois terços do quadro para a paisagem árida? Por que não ilustrar o texto com uma foto da produção bem-sucedida do Uruguai, mencionada no conteúdo linguístico?

0 retrato captado naquele momento imprime um significado à análise discursiva. "Travar o movimento é a opção mais comum no fotojornalismo. Os gestos significativos, as posições sugestivas, precisam frequentemente de ser 'congeladas' para que lhes possa ser imposto um sentido" (Sousa, 2004a, p. 123). A imagem da mulher perante a plantação provoca sensações que variam de interlocutor para interlocutor. Porém, há um direcionamento orientador na interpretação que se vale dos modelos mentais e acervos cognitivos elaborados ao longo do tempo pelos destinatários.

Dossiê 0 Pensamento Ecológico - https://revistaecopos.eco.ufrj.br/

ISSN $2175-8689$ - v. 23, n. 2, 2020

DOI: 10.29146/eco-pos.v23i2.27511 
A interpretação desta imagem feita por um morador da região semiárida e que vivencia as mesmas experiências da personagem será distinta daquela elaborada por um leitor urbano, distante daquela realidade e desconectado do universo rural. Até mesmo entre interlocutores ligados ao ambiente rural outras leituras são possíveis dada a complexidade das percepções e imaginários dos sujeitos. Ou seja, a atribuição de sentidos aos discursos depende do repertório de cada interlocutor, da cultura compartilhada entre autor e receptor e de processos psicossociocognitivos de percepção, retenção, memorização, discriminação, avaliação e compreensão do que se percebe (Charaudeau, 2019).

Um especialista em agricultura poderia interpretar, por exemplo, que o restolho do milho retratado na foto é favorável a uma safra vindoura ${ }^{2}$, podendo, inclusive, fazer parte de uma tecnologia que facilita a retenção de água no solo. Já um profissional sem qualquer vínculo com a produção agrícola poderia reportar leitura completamente diferente, atestando as noções de seca e de fome. A ambiguidade advém desta limitação de informações do conteúdo imagético que remete a uma projeção.

0 movimento do olhar da personagem em direção à plantação seca indica uma continuidade daquele cenário, como se a desertificação fosse um fenômeno "sem fim", já que a imagem não revela os limites do ambiente árido. A tonalidade da seca, amarelo-dourado, é predominante e reforça o conceito de "estereótipo adaptado" de Gombrich (1995), em que "durante o processo de produção de imagens, tende-se a buscar um vínculo com um padrão - um estereótipo existente estabilizado na cultura, requerendo, tão somente, o trabalho de adaptá-lo às necessidades do momento" (Soares; Ferreira, 2017, p. 186).

\footnotetext{
2 Restolho é o nome dado às folhas e caules de cereais como o milho, sorgo e soja que são deixados nos campos após as colheitas. Podem ser diretamente fornecidos ao gado ou secos para forragem animal. Sendo semelhante à palha, o resíduo deixado após a colheita de cereais tem ainda potencial econômico. 0 restolho pode ainda ser um combustível e fonte de biomassa para fermentação e produção de etanol celulósico. A presença de restolho sobre o terreno é como uma "armadilha" para a retenção de água, pois facilita a infiltração e reduz as perdas por evaporação ao manter mais fria e protegida a superfície do solo. Esta conceção é fulcral num correto sistema de cultivo de plantio direto. (Restolho, 2020).
}

Dossiê 0 Pensamento Ecológico - https://revistaecopos.eco.ufrj.br/

ISSN 2175-8689 - v. 23, n. 2, 2020

DOI: 10.29146/eco-pos.v23i2.27511 
Constitui-se, assim, uma associação presumida do cenário seco ao tema degradação do solo, induzida, possivelmente, por padrões técnicos estereotipados editoriais e individuais - cada artista ou fotógrafo os herdam naturalmente. Historicamente, o Grupo Globo, que edita o Portal G1, estabeleceu alguns padrões ambientais midiáticos que relacionam o Pantanal à área alagada (Maio, 2009), a Amazônia à floresta (Dutra, 2001) e o Nordeste brasileiro à seca (Leitão; Santos, 2012; Alves, 2018; Silva; Massuchin, 2019). Ou seja, ao fotografar uma cena, o profissional já possui uma preconcepção imaginária das conexões que precisa criar para produzir o efeito de sentido desejado e abastecer o processo de significação.

Outro conceito aplicável à análise é o "princípio do etc", também de Gombrich (1995), segundo o qual a imagem não precisa representar detalhes em seu enunciado porque a mente humana, observando alguns elementos, é capaz de imaginar e ver o todo. Essa tendência de ilusão, no entanto, pode resultar em equívocos, já que em situações nas quais não se sabe nada acerca do tipo de superfície apresentada, a interpretação pode ser ainda mais inadequada (Gombrich, 1995). Esta ponderação do historiador evoca, novamente, o protagonismo do destinatário no processo de atribuição de sentido.

\section{Considerações finais}

Ao se depreender sentidos pregnantes em imagens fotojornalísticas e analisar-se as possíveis intencionalidades que levam o sujeito-enunciador a incorporar certas posições ideológicas na organização e no funcionamento do discurso, torna-se relevante situá-lo em sua conjuntura histórico-social e levar em conta como a cultura, as subjetividades, os constrangimentos organizacionais, as políticas editoriais, os imaginários etc. influenciam na produção fotojornalística.

Estudar uma imagem significa fechar o foco, precisar o objeto a ser analisado e apreender os sentidos que não figuram na estrutura visível da fotografia, já que habitam lugares obscuros da linguagem fotográfica, que é opaca como todo discurso. A análise de imagem busca a compreensão das mensagens visuais como produtos comunicacionais, cujo esforço de interpretação pressupõe a imbricação com a 
cultura, o social, o histórico e a formação social dos sujeitos, revelando de que modo a relação imagem/interpretação pode ser "administrada" em várias instâncias (Souza, 2015).

O discurso fotográfico foi analisado pela metodologia proposta por Soares e Ferreira (2017), baseada na análise discursiva da imagem (Barthes, 1984, 2009) e na psicologia da percepção de Gombrich (1995). De acordo com essa perspectiva, o enunciado se classifica na categoria focalização: a temporalidade desencadeada coincide com os estudos divulgados sobre degradação de solo. A atribuição de sentido, no entanto, envolve incertezas nas relações entre os elementos da imagem e o conteúdo textual.

A ambiguidade está presente no enunciado fotográfico pela falta de informações específicas sobre a imagem. Sabe-se que o restolho do milho, representado na foto, pode ser interpretado de forma positiva ou negativa, dependendo do contexto. A legenda induz o interlocutor a uma leitura negativa, citando a desertificação. Porém, a mesma imagem talvez pudesse ilustrar a técnica do plantio direto, e aquele milho seco e amarelado poderia indicar a viabilização de uma nova safra, garantia de alimento e renda para a família que trabalha no campo.

Ressalvado o caráter ambíguo da imagem e considerando a interpretação negativa do cenário que vislumbra a seca e a desertificação, infere-se que componentes da fotografia sugerem a perda da capacidade de produção pela atividade agrícola, conforme mencionado no título da matéria. 0 discurso imagético não apenas reitera, mas amplifica essa ideia, sinalizando a perda total da produção, e não da metade, como indica o conteúdo verbal. Essa percepção advém da aplicação do "princípio do etc", que induz o observador a completar a cena. Nada naquela imagem sugere que o restolho do milho e as árvores secas ao fundo se limitem ao quadro retratado. É como se as molduras apenas cercassem uma imagem que expressa além.

A interpretação revela, ainda, forte dependência da imagem com o conteúdo verbal adjacente. A estrutura conotativa associa a fotografia à noção de fome relação que o enunciado verbal silencia -, porém a imagem não conduz, per se, à ideia de que as erosões e a degradação do solo seriam as responsáveis pelo cenário 
captado. A predominância da cor amarelada remete mais à ideia de seca, de um fenômeno climático. Para traçar essa correlação, o enunciatário precisa ler o título, a legenda e/ou o texto.

Com base nesses resultados, conclui-se que o discurso fotográfico apresentado ao leitor urbano reforça o estereótipo da seca e da fome da região semiárida brasileira, acrescentando a ideia de que existe um desequilíbrio ambiental interferindo na produção de alimentos. No entanto, a conexão da imagem com a ideia de degradação de solo é menos palpável do que a noção de que a produção agrícola sofreu prejuízos, esta sim, mais explícita.

\section{Referências bibliográficas}

ALVES, Allana Shirley de Melo. A construção imagética da região nordeste. Trabalho de Conclusão de Curso (Especialização)- Universidade Federal de Alagoas, Delmiro Gouveia, 2018. Disponível em: http://www.repositorio.ufal.br/bitstream/riufal/3653/1/A\%20constru\%c3\%a7\%c3\%a3 o\%20imag\%c3\%a9tica\%20da\%20Regi\%c3\%a30\%20Nordeste.pdf. Acesso em: 11 jun. 2020.

BARTHES, Roland. A câmara clara: nota sobre a fotografia. Tradução de Júlio Castañon Guimarães. Rio de Janeiro: Nova Fronteira, 1984.

BARTHES, Roland. O óbvio e o obtuso. São Paulo: Edições 70, 2009.

CHARAUDEAU, Patrick.; MAINGUENEAU, Dominique. Dicionário de análise do discurso. 3. ed. São Paulo: Contexto, 2016.

CHARAUDEAU, Patrick. Discurso das Mídias. São Paulo: Contexto, 2019.

COUTINHO, Iluska. Leitura e análise de imagem. In: DUARTE, Jorge; BARROS, Antonio (Orgs). Métodos e técnicas de pesquisa em comunicação. 2. ed. São Paulo: Atlas, 2008. p. 330-344.

DUTRA, Manual José Sena. A Amazônia na TV: produção de sentido e o discurso da ecologia. In: CONGRESSO BRASILEIRO DA COMUNICAÇÃO, 24., 2001, Campo Grande. Anais [...]. Campo Grande: Intercom, 2001. p. 31-52. Disponível em:

http://www.intercom.org.br/papers/nacionais/2001/papers/NP9DUTRA.PDF. Acesso em: 11 jun. 2020.

EROSÃO do solo pode reduzir rendimento de plantações pela metade, diz ONU. Portal G1, Rio de Janeiro, 15 maio 2019. Disponível em:

Dossiê 0 Pensamento Ecológico - https://revistaecopos.eco.ufrj.br/

ISSN 2175-8689 - v. 23, n. 2, 2020

DOI: 10.29146/eco-pos.v23i2.27511 
https://g1.globo.com/natureza/noticia/2019/05/15/erosao-do-solo-pode-reduzirrendimento-de-plantacoes-pela-metade-diz-onu.ghtml. Acesso em: 23 fev. 2020.

GOMBRICH, Ernst. Arte e ilusão: um estudo da psicologia da representação pictórica. Tradução de Raul de Sá Barbosa. São Paulo: Martins Fontes, 1995.

GROSSI, Marina. Davos e sustentabilidade. Cebds, Rio de Janeiro, 22 jan, 2019. Disponível em: https://cebds.org/davos-e-a-sustentabilidade/\#.XpxS-Zl7mUl. Acesso em: 19 abr. 2020.

JOLY, Martine. Introdução à análise de imagem. Tradução de Marina Appenzeller. Campinas: Papirus, 1996.

LEITÃO, Juliana Andrade; SANTOS, Maria Salett Tauk. Imagem jornalística e representações sociais: a imagem dos Sertões. Intercom - Revista Brasileira de Ciências da Comunicação, v. 35, n. 1, p. 133-155, jan./jun. 2012. Disponível em: https://www.scielo.br/pdf/interc/v35n1/08.pdf. Acesso em: 11 jun. 2020.

MAIO, Ana Maria Dantas de. Comunicação e representações sociais: o Pantanal que os brasileiros (des) conhecem. Estudos em Comunicação, n. 5, p. 217-226, maio 2009.

ONU: fome atinge mais de 820 milhões de pessoas no mundo. ONU News, Nova Iorque, 15 jul. 2019. Disponível em: https://news.un.org/pt/story/2019/07/1680101. Acesso em: 12 abr. 2020.

PEREIRA, Flora. Líderes mundiais se reúnem no maior fórum ambiental da ONU para defender economias sustentáveis. Pnuma, Nairóbi, 10 mar. 2019. Disponível em: https://www.unenvironment.org/pt-br/noticias-e-reportagens/press-release/lideresmundiais-se-reunem-no-maior-forum-ambiental-da-onu. Acesso em: 19 abr. 2020.

RESTOLHO. In: Wikipédia: a enciclopédia livre, 2020. Disponível em: https://pt.wikipedia.org/wiki/Restolho. Acesso em: 8 jun. 2020.

SILVA, Frederico Augusto Barbosa da; ZIVIANI, Paula; GHEZZI, Daniela Ribas. As tecnologias digitais e seus usos. Rio de Janeiro: Ipea, 2019. (Texto para discussão, 2470). Disponível em:

http://www.ipea.gov.br/portal/images/stories/PDFs/TDs/td uuu2470.pdf. Acesso em: 12 abr. 2020.

SILVA, Sarah Dantas do Rego; MASSUCHIN, Michele Goulart. Aspectos regionais no telejornalismo nacional: uma análise de conteúdo qualitativa da representação do nordeste no Jornal Hoje. In: CONGRESSO DE CIÊNCIAS DA COMUNICAÇÃO NA REGIÃO NORDESTE, 21., 2019, São Luís. Anais [...]. São Luís, Intercom Nordeste, 2019. p. 1-15. Disponível em: http://portalintercom.org.br/anais/nordeste2019/resumos/R67-08721.pdf. Acesso em: 11 jun. 2020.

SOARES, Nelson; FERREIRA, Giovandro Marcus. Discurso e imagem: possibilidades metodológicas para uma análise discursiva do fotojornalismo contemporâneo. Intexto, n. 39, p. 177-200, maio/ago. 2017. Disponível em: https://seer.ufrgs.br/intexto/article/view/64907/40292. Acesso em: 20 fev. 2020.

Dossiê 0 Pensamento Ecológico - https://revistaecopos.eco.ufrj.br/

ISSN $2175-8689$ - v. 23, n. 2, 2020

DOI: 10.29146/eco-pos.v23i2.27511 
SOUSA, Jorge Pedro. Análise qualitativa do discurso fotográfico dos meios jornalísticos impressos. In: SOUSA, Jorge Pedro. Introdução à análise do discurso jornalístico impresso: um guia para estudantes de graduação. Florianópolis: Letras Contemporâneas, 2004a. p. 113-132.

SOUSA, Jorge Pedro. Fotojornalismo: introdução à história, às técnicas e à linguagem da fotografia na imprensa. Florianópolis: Letras Contemporâneas, 2004b.

SOUZA, Tania Conceição Clemente de. A análise do não verbal e os usos da imagem nos meios de comunicação. Rua, v. 7, n. 1, p. 65-94, out. 2015 Disponível em:

https://doi.org/10.20396/rua.v7i1.8640721. Acesso em: 1o maio. 